\title{
The Recovery Of Assets Results Of Corruption Through Additional Criminal Payment of Replacement Money
}

\author{
Hery Purwanto*) and Siti Ummu Adillah**) \\ *) Prosecutor at Jombang District Attorney E-mail: \\ herypurwanto.unissula@gmail.com \\ **) Faculty of Law Universitas Islam Sultan Agung
}

\begin{abstract}
This study aims to identify and examine efforts to recover assets resulting from criminal acts of corruption through additional criminal payments of replacement money. This study uses a normative juridical approach, which is descriptive analysis. The data used is secondary data obtained through literature study, which is then analyzed qualitatively. The results of this study are efforts to recover assets resulting from criminal acts of corruption through additional criminal payments of replacement money based on the provisions of Article 18 paragraph (1) letter b of Act No. 31 of 1999 jo. Act No. 20 of 2001. The purpose of imposing additional penalties is to ensure that state financial losses caused by actions can be recovered to the state through the imposition of additional penalties for payment of compensation. The judge in deciding the amount of additional criminal payment of compensation to the defendant based on legal facts at trial that prove the amount of property obtained by the defendant from the crime of corruption.

Keywords: Corruption; Asset Recovery; Crime; Reimbursement.
\end{abstract}

\section{Introduction}

The State of Indonesia is a state of law, as mandated by the provisions of Article 1 paragraph (3) of the 1945 Constitution of the Republic of Indonesia, that: "The State of Indonesia is a state of law", so both in the administration of the state or government as well as in social life must not deviate from the rule of law or statutory regulations that have been established, and the Indonesian state is a welfare state that aims to realize the hopes of its citizens for an orderly, just and prosperous life, as mandated by the Fourth Paragraph of the Preamble to the Law. 1945 Constitution of the Republic of Indonesia.

As a legal state that aims to realize general welfare, the government seeks to carry out development in all fields, both economic, political, social, cultural, defense and security. However, these development efforts have been hampered by acts of corruption by state administrators and officials, who are supposed to carry out the people's mandate to run a just and corruption-free state and government.

Corruption is a very old social problem, which may be as old as human civilization itself. Corruption is basically an evolutionary crime, which grows and develops dynamically along with the pace of development of the times. Therefore, time after time, the variety of corruption is increasing, and the techniques are getting more sophisticated. Initially the form of corruption was only in the form of 
bribes, but now the crime has developed into a variety of modus operandi, which is far from the legislation that fights it. ${ }^{1}$

Corruption has become one of the big and serious problems that are being faced by the Indonesian people. The high level of corruption in Indonesia indicates that corruption in this country has spread to various fields of people's lives and has been going on for a relatively long time. Corruption has become a kind of phenomenon of everyday life in Indonesia. ${ }^{2}$ Corruption is also believed to be the root of all national problems and the main cause of poverty. ${ }^{3}$

For this reason, it is necessary to prevent and overcome corruption through law enforcement policies through legal instruments for recovering assets acquired from corruption, in this case the criminal law instrument for payment of replacement money. In general, the public recognizes the law as a rule, norm, guideline, behavior, or statutory regulation which if violated will be subject to sanctions. This understanding is very easy to understand by the community, because people who are wrong or violate the rules must be punished. ${ }^{4}$ Every act or action that is against the law, will get criminal sanctions as regulated in criminal law. The essence of criminal law is the imposition of suffering or misery or other unpleasant consequences. ${ }^{5}$

Various strategies have been carried out for the recovery of assets obtained from corruption, and the recovery of assets resulting from corruption through the national legal system has a strategic position, both through criminal law instruments and civil law in accordance with the provisions of Act No. 31 of 1999 jo. Act No. 20 of 2001 concerning the Eradication of Corruption Crimes. The enactment of Act No. 31 of 1999 was intended to perfect and at the same time replace Act No. 3 of 1971 concerning the Eradication of Corruption Crimes (PTPK). ${ }^{6}$

Government legislation policy in the form of Act No. 31 of 1999 jo. Act No. 20 of 2001 through the application of the threat of capital punishment, imprisonment, fines, additional penalties for paying replacement money and state civil claims by the State Attorney (JPN) or by the agency that has been harmed has not been able to have a positive impact on prevention and tackling corruption crimes and efforts to recover assets obtained from corruption, there are even court decisions in

\footnotetext{
1Wahju Prijo Djatmiko, 2020, Politik Kriminal Pemberantasan Tindak Pidana Korupsi Perspektif Budaya Hukum, Sixth Printing, Thafa Media, Yogyakarta, p. 10.

${ }^{2}$ Rakhmat Bowo Suharto and Cipto Dwi Leksana, Maret 2019, Implementation of Cooperation Agreement Between the Ministry of Internal Affairs, Police, Attorney General Office (Ago) in Handling and Crime Of Corruption in Indonesia, Jurnal Daulat Hukum, Vol. 2 No. 1, Faculty of Law, Universitas Islam Sultan Agung, Semarang, p. 123, url : http://jurnal.unissula. ac.id/index.php/RH/article/view/4217/2923.

${ }^{3}$ Febby Mutiara Nelson, 2020, Plea Bargaining \& Deferred Prosecution Agreement Dalam Tindak Pidana Korupsi, First Printing, Sinar Graphic, Jakarta, p. 1.

4Jawade Hafidz Arsyad and Dian Karisma, 2018, Sentralisasi Birokrasi Pengadaan Barang \& Jasa Pemerintah, First Printing, Sinar Graphic, Jakarta, p. 63.

${ }^{5}$ Sri Endah Wahyuningsih, 2013, Prinsip-Prinsip Individualisasi Pidana Dalam Hukum Pidana Islam dan Pembaharuan Hukum Pidana Indonesia, Second Printing, Publishing Agency Diponegoro University, Semarang, p. 80.

${ }^{6}$ Rodliyah and Salim HS, 2019, Hukum Pidana Khusus, Unsur dan Sanksi Pidananya, First Edition, Second Printing, Rajawali Press, Depok, p. 32-34.
} 
corruption cases that are light and acquitted so that they do not cause a deterrent effect.

Legislation policy of the birth of Act No. 31 of 1999 jo. Act No. 20 of 2001, essentially aims to save state assets so that the funds are guaranteed to be used, namely for national development to create a prosperous, just and prosperous Indonesian society as mandated by the Constitution of the 1945 Constitution of the Republic of Indonesia. Therefore, the legal instrument for recovering assets obtained from corruption in the form of additional criminal penalties for payment of replacement money has an important role in recovering assets resulting from corruption illegally controlled by other parties.

According to Romli Atmasasmita that currently the direction, purpose and mission of law enforcement in eradicating corruption is unclear or there is a disorientation in law enforcement, among others, because the return of state (financial) losses has not been significantly successful compared to the State Budget (APBN) that has been implemented. issued to law enforcement agencies, as well as the purpose of sentencing to detain the perpetrators is also not maximally achieved because in addition to the discretionary treatment allowed by the Correctional Law, there is also discretion according to the Criminal Procedure Code (KUHAP) from investigation to prosecution. This is discriminatory, especially for perpetrators who do not have political power and money power. ${ }^{7}$

The crime of corruption is a crime against property or wealth, in this case property or property belonging to the state, so that the state suffers losses due to corruption. Therefore, the main thing in eradicating criminal acts of corruption is to recover assets resulting from criminal acts of corruption by returning the state's financial losses that were corrupted. The payment of replacement money is expected to be able to recover assets resulting from criminal acts of corruption and take all the proceeds from corruption crimes from the perpetrators of criminal acts of corruption.

The purpose of this study is to find out and examine efforts to recover assets resulting from criminal acts of corruption through additional criminal payments of replacement money.

\section{Research Methods}

The type of research used in writing this legal journal is normative juridical. Normative juridical research is research that is focused on examining the application of rules or norms in positive law, ${ }^{8}$ which in this case relates to the recovery of assets resulting from criminal acts of corruption through additional criminal payments of replacement money. This research is descriptive analysis, because the researcher wishes to describe or explain the subject and object of research, which then analyzes and finally draws conclusions from the results of the

\footnotetext{
${ }^{7}$ Sujono, 2020, Pemulihan Aset Korupsi Melalui Pembayaran Uang Pengganti dan Gugatan Perdata Negara, First Printing, Genta Publishing, Yogyakarta, p. 5.

8Jhonny Ibrahim, 2011, Teori dan Metodologi Penelitian Hukum Normatif, Bayumedia, Malang, p. 295.
} 
study. ${ }^{9}$ The data used in this research is secondary data. Secondary data is data obtained from library materials through library research, and this data is also obtained from agencies/institutions related to the purpose of this research. ${ }^{10}$ According to the data that has been obtained during the research by reading library books, then it is analyzed. The analysis used in this research is qualitative data analysis.

\section{Results and Discussion}

Corruption is a disease that has plagued Indonesia. Like a disease, this corruption must be cured so that it does not spread to other parts of the body. For body parts that have decayed and cannot be saved anymore, then that body part must be amputated so that the virus does not spread to other parts that can endanger the life of the sufferer, as well as corruption. ${ }^{11}$

Corruption is an act that can cause harm to many parties, and can even affect the existence and development of the progress and welfare of the people of a country. ${ }^{12}$ Corruption in this country, so deep-rooted and widespread that usually occurs in the center of government, has now penetrated even at lower levels such as in the regions and villages. Not only in government, but also in court, corporate, education, all aspects of life. ${ }^{13}$

Forms of corrupt practices grow and develop over time, both in quality and quantity, ${ }^{14}$ and the development of corruption in Indonesia is still relatively high, while its eradication is still very slow. ${ }^{15}$ The thing that is highly anticipated is the criminal decision handed down by the judge which provides a deterrent effect for corruptors and can return assets resulting from corruption.

Judges as components of the legal structure have the authority to examine and hear or decide cases. Regarding corruption case decisions, ideally it should consider the past as the theory of retaliation and the future such as the theory of

\footnotetext{
${ }^{9}$ Mukti Fajar ND and Yulianto Achmad, 2010, Dualisme Penelitian Hukum Normatif dan Empiris, Pustaka Pelajar, Yogyakarta, p. 183.

${ }^{10}$ Soeratno and Lincolin Arsyad, 2003, Metodologi Penelitian Untuk Ekonomi Dan Bisnis, UPP AMP YKPN, Yogyakarta, p. 173.

${ }^{11}$ Jawade Hafidz Arsyad, 2013, Korupsi Dalam Perspektif HAN (Hukum Administrasi Negara, First Printing, Sinar Graphic, Jakarta, p. 3.

${ }^{12}$ Hulman Siregar, March 2018, Rumusan Pidana dan Pemidanaan Tindak pidana Korupsi Yang Merugikan Keuangan Negara Serta Permasalaan Dalam Penerapannya, Jurnal Daulat Hukum, Vol. 1. No. 1, Faculty of Law, UNISSULA, Semarang

${ }^{13}$ Luk Har Syan'in, Gunarto, and Widayati, March 2019, Criminal Investigation Polres Kudus Unit Efforts In The Prevention Of The Corruption In Village Funds Management, Jurnal Daulat Hukum, Vol. 2 No. 1, Faculty of Law, UNISSULA Semarang, p. 69, url : http://journal. unissula.ac.id/index.php/RH/article/view/4208/2914.

${ }^{14}$ Hulman Siregar and Rakhmat Bowo Suharto, September 2018, Analysis and Review of The Implementation of Law Enforcement Operations Juridical Capture Corruption in The Criminal Justice System, Jurnal Daulat Hukum, Vol. 1 No. 3, Faculty of Law, UNISSULA Semarang, p. 844, url : http://jurnal.unissula.ac.id/index.php/RH/article/view/3412/2521.

15Muhamad Riyadi Putra and Gunarto, Analysis Of Handling Practices On Corruption Crime By Police (Case Study In Special Criminal Investigation Police Directorate Of Central Java), Jurnal Daulat Hukum, Vol. 2 No. 2, Faculty of Law, UNISSULA Semarang, June 2019, p. 209, url : http://jurnal.unissula.ac.id/index.php/RH/article/view/5425/3346.
} 
goals or known as the combined theory. Thus, the imposition of a criminal sentence must provide a sense of satisfaction for both the judge and the criminal himself in addition to the community. ${ }^{16}$

Independent judicial power and the principle of freedom of judges does not mean that judges can do whatever they want. Especially if the judge takes refuge behind the power of the judiciary and behind the freedom of the judge to decide cases that are not based on the law. Judges remain bound by legal provisions. There must be legal reasoning for all decisions made. It must also be in line with the spirit of the country and nation where the judges work. ${ }^{17}$ The imposition of criminal sanctions for corruptors by judges must really be able to provide justice for the community.

In tackling corruption, the main issue is asset recovery for corruption, in addition to preventing and eradicating corruption. ${ }^{18}$ In the recovery of criminal assets, the definition of "entitled" is the victim of a crime whose assets or assets are confiscated or illegally controlled by the perpetrators of crime. In other words, assets resulting from or related to the crime must be recovered for the benefit of the victim. In this case, the state has an obligation to recover these assets. ${ }^{19}$ One of the ways is to impose a penalty for payment of substitute money, which really must be carried out without a subsidiary decision to impose a substitute imprisonment.

Satisfaction with the community related to the imposition of a substitute prison sentence must encourage the convict to choose to pay replacement money and not choose to undergo a substitute prison sentence, because in corruption cases the goal of the perpetrator is to gain economic benefits, and of course the aim of obtaining economic benefits illegally must be prevented. . Therefore, it is more appropriate to impose a heavy substitute prison sentence even though at first glance it is contrary to the efficient principle because imprisonment is considered inefficient. Makhrus Ali mentions in other words, criminals are economic rational beings who weigh the costs that must be incurred from committing crimes with the benefits that will be obtained. ${ }^{20}$

Article 18 paragraph (1) letter b of Act No. 31 of 1999 jo. Act No. 20 of 2001, states that in addition to the additional punishment as referred to in the Criminal Code, as an additional penalty is the payment of replacement money in the maximum amount equal to the property obtained from the criminal act of corruption.

The legal implications of Article 18 paragraph (1) letter b of Act No. 31 of 1999 jo. Act No. 20 of 2001, including in the case of corruption cases Article 2 and Article 3 of Act No. 31 of 1999 jo. Act No. 20 of 2001 which requires state financial

\footnotetext{
${ }^{16}$ S.R Sianturi, 2012, Asas-Asas Hukum Pidana Di Indonesia dan Penerapannya, Babinkum TNI, Jakarta, p. 62.

17Imam Anshori Saleh, 2017, Korupsi, Terorisme dan Narkoba, Upaya Melawan Kejahatan Luar Biasa yang Sistematis, First Printing, Setara Press, Malang, p. 57.

${ }^{18}$ Agustinus Herimulyanto, 2019, Sita Berbasis Nilai Pengembalian Aset Tindak Pidana Korupsi, First Printing, Genta Publishing, Yogyakarta, p. 1.

${ }^{19}$ Chuck Suryosumpeno, 2020, Rezim Pemulihan Aset, Antara Dibenci dan Dibutuhkan, First Printing, REQBook, Jakarta, p. 64-65.

20Makhrus Ali, 2016, Hukum Pidana Korupsi, UII Press, Yogyakarta, p. 234.
} 
losses, even though there has been a real loss of state finances, but the judge cannot impose an additional penalty for paying replacement money, if the defendant does not obtain assets or profits from the corruption incident, thus the state is still the victim.

The purpose of imposing additional criminal payments of compensation to the defendant whose process begins at the investigation stage through the confiscation and tracing of the suspect's assets by investigators is to ensure that state financial losses caused by the defendant's corruption can ultimately be recovered to the state through the imposition of a criminal offence additional payment of the replacement money. Therefore, the understanding of imposing additional criminal payments for replacement money is interpreted broadly, namely not only when the judge calculates and makes a criminal decision on additional payment of replacement money, but must look at it from the investigation stage through legal action for confiscation of assets, both against assets that are directly related to the case and assets of the suspect that are not related to the case. ${ }^{21}$

The practice of recovering the acquisition of assets resulting from corruption in an effort to recover state financial losses through criminal law instruments in the form of imposing additional criminal payments for replacement money is carried out through the initial stages of investigation.

At the investigation stage, investigators at the Police or the KPK or the Prosecutor's Office in handling corruption cases submit a request to the agency authorized to calculate state financial losses to become an expert, in this case it can be submitted to the BPK RI, BPKP and Bawasda or a public accountant or from the Inspectorate of the Ministry / Institution. This request for calculating state financial losses refers to the Elucidation of Article 32 of Act No. 31 of 1999 jo. Act No. 20 of 2001, which means that there has been a real state financial loss is a state loss whose amount can be calculated based on the findings of the authorized agency or appointed public accountant. ${ }^{22}$

The results of the calculation of losses, in addition to containing the total state financial losses, also include details of state financial losses enjoyed or obtained by the suspect unlawfully, then the results of the calculation serve as the basis for determining the amount of state financial losses in the indictment and the basis for prosecuting the Public Prosecutor in the prosecution payment of replacement money as an additional penalty. Therefore, in the case of corruption, it is possible that the total loss of state finances as a whole will be the responsibility of the convict to return it, or only part of it, namely as much as the same as the property obtained by the defendant from the criminal act of corruption, which is then set forth in the dictum of the court's decision. ${ }^{23}$

The Public Prosecutor in criminal charges against the defendant will demand that the defendant is proven to have committed a criminal act of corruption in accordance with Article 2 or Article 3 of Act No. 31 of 1999 jo. Act No. 20 of 2001 is accompanied by demands that the principal and additional penalties be imposed for

\footnotetext{
${ }^{21}$ Sujono, op.cit., p. 45.

${ }^{22}$ Ibid., p. 77.

23Ibid., p. 78. 
payment of compensation for state financial losses in the amount that has been determined, and if within 1 (one) month after the criminal decision against the defendant has permanent legal force, the convict cannot to pay compensation in the amount of the amount in the decision, the defendant shall be sentenced to a substitute imprisonment for a certain period of time determined by the Public Prosecutor. ${ }^{24}$

The ratio of the maximum period of one month if the convict is unable to pay compensation for state losses will be subject to a substitute prison sentence which is considered too short, so the provisions for a maximum period of one month need to be reviewed or reconstructed to be extended through legislation policy.

The facts of state financial losses and the defendant's property obtained from corruption according to the indictment of the Public Prosecutor will be tested. In trial practice, if there is a use of state finances that is not enjoyed by the defendant, it will be deducted from the amount of state financial losses, then only property according to legal facts at trial that is enjoyed or obtained by the defendant from the proceeds of corruption which is the basis for the judge to decide the amount of money payment. substitute, although there are several judges' decisions that determine the amount of payment of compensation by calculating the assets obtained by the defendant plus money used by the defendant illegally, for example to finance activities or social assistance or giving to other parties who are not their duties and authorities. ${ }^{25}$

The profit from the proceeds of corruption obtained by the defendant which is proven at trial will be the basis for the decision on the amount of compensation to be paid to the defendant. The additional criminal imposition of compensation payments by the judge is not always included, in this case if the defendant's property which has been confiscated during the criminal process has reached a minimum value equal to the state financial loss or the amount of property obtained by the defendant in a corruption crime. The amount of replacement money paid by the convict is as much as the assets or profits obtained by the convict related to the corruption crime committed, so that the amount of compensation payment may be smaller than the state financial loss. ${ }^{26}$

In the practice of court decisions in cases of corruption, the judge in deciding the amount of additional criminal payment of compensation for the defendant based on legal facts at trial that prove the amount of property obtained by the defendant (the defendant's profit) from the criminal act of corruption as stipulated in Article 18 paragraph (1) letter b of Act No. 31 of 1999 jo. Act No. 20 of 2001. Article 18 paragraph (1) letter b of Act No. 31 of 1999 jo. Act No. 20 of 2001, states that: "In addition to the additional punishment as referred to in the Criminal Code, as an additional crime is the payment of replacement money in the maximum amount equal to the property obtained from the criminal act of corruption".

The implication is that not all cases of corruption, even though based on legal facts at trial, it has been proven that there is a state financial loss, it is always

\footnotetext{
${ }^{24}$ Ibid., p. 79.

25 Ibid.

26Ibid., p. 80.
} 
accompanied by the imposition of additional criminal payments for replacement money if the defendant is not proven to have made a profit or obtained property from a criminal act of corruption.

In the practice of imposing additional criminal payments for replacement money and its realization, the nominal payment of replacement money as stated in the decision can be extreme, it can be said that only decisions on paper have not been able to realize the purpose of the legal norm of paying replacement money, namely saving state assets, because the convicts only pays part of the nominal value of the decision and the payment is made through the mechanism for calculating the proceeds from the sale of assets. Because the payment is only partial, the convict continues to serve the full term of the subsidiary prison sentence. It can be illustrated, for example, the convict is sentenced to an additional payment of 10 billion in replacement money with a subsidiary imprisonment of 5 years. ${ }^{27}$

The absence of conversion provisions and the fact that conversion has not been implemented in practice, gives a message to corruptors to be smarter in hiding the assets resulting from corruption rather than showing or handing over their assets. Furthermore, cutting the prison sentence for a substitute or subsidiary by taking into account the assets that have been and will be paid for conversion, can encourage the convict to pay the maximum replacement money.

Another effort in terms of recovering assets resulting from corruption is through state civil lawsuits either by the State Attorney or the agency that is harmed is so that there is no gap in state financial losses due to corruption, or in other words that the purpose of state civil lawsuits is to guarantee all state financial losses. can be reinstated back to the state, even though there is insufficient evidence of the suspect's actions so that the legal process is terminated, the suspect or defendant's case dies due to death, the suspect or defendant's case is not proceeded with the legal process because the suspect/defendant does not meet health requirements even if the defendant's case is acquitted by court, what is important in the case is that the element of real state financial loss is met.

Although efforts to restore state finances are continuously carried out by State Attorneys, the various weaknesses of civil instruments in efforts to restore state finances are a necessity due to the fact that procedural law instruments are available. Therefore, there must be a breakthrough in the framework of legal reform. If within the area of corruption is a special category of crime, there must be a big idea to encourage the definition of a civil lawsuit specifically, namely specifically in the context of a lawsuit for the return of state finances. The consequence is that civil lawsuits cannot only be based on the provisions stipulated in the applicable Civil Procedure Code, namely HIR, which in fact is less aggressive in supporting civil claims for the return of state finances. ${ }^{28}$

In order to recover assets resulting from corruption, synergy and cooperation between law enforcers is needed. According to Marwan Effendy, the eradication of corruption is carried out by several institutions, including the

\footnotetext{
27Ibid., p. 93-94.

${ }^{28}$ Bambang Setyo Wahyudi, 2016, Pengembalian Kerugian Negara Melalui Tuntutan Pencucian Uang dan Gugatan Perdata, First Printing, Hanif Library, Surakarta, p. 159.
} 
Prosecutor's Office and the KPK by involving other relevant agencies such as PPATK, BPK, and BPKP as auditor institutions whose role is to audit the amount of state financial losses and the amount of state money taken due to criminal acts important and strategic corruption. Through good and professional synergy and cooperation between these institutions, the task of eradicating corruption will be more effective and provide the expected results. ${ }^{29}$

The return of state losses through substitute money is more beneficial than having to imprison the perpetrator in a correctional institution. Imprisonment sanctions have not yet been able to show a deterrent effect for perpetrators of corruption, in fact the more corruptors who are subject to imprisonment, the corruption rate is increasing. Imprisonment if applied in corruption cases as the most important sanction is deemed inappropriate, considering corruption as an economic crime, the orientation of the perpetrators is on the calculation of profit and loss. Before committing corruption, state officials will usually calculate in advance how much the costs will be with the money that will be received after the act is completed. ${ }^{30}$

\section{Closing}

Efforts to recover assets resulting from criminal acts of corruption through additional criminal payments of replacement money are based on provisions Article 18 paragraph (1) letter b of Act No. 31 of 1999 jo. Act No. 20 of 2001. The purpose of imposing additional penalties is to ensure that state financial losses resulting from the defendant's corruption can ultimately be recovered to the state through additional criminal penalties for payment of compensation. The judge in deciding the amount of additional criminal payment of compensation to the defendant based on legal facts at trial that prove the amount of property obtained by the defendant from the crime of corruption.

The suggestion put forward is that it is necessary to revise Act No. 31 of 1999 jo. Act No. 20 of 2001 is related to the conversion of the criminal payment of replacement money to an alternate prison term. In addition, it is also necessary to carry out legal reconstruction which stipulates that the property obtained by the defendant is not only property that is directly enjoyed by the defendant, but includes property that is not directly enjoyed by the defendant, in this case the proceeds are owned by another party for confiscation.

\section{References}

\section{Journal}

[1] Hulman Siregar and Rakhmat Bowo Suharto, September 2018, Analysis and Review of The Implementation of Law Enforcement Operations Juridical Capture Corruption in The Criminal Justice System, Jurnal Daulat Hukum, Vol. 1 No. 3,

\footnotetext{
${ }^{29}$ Marwan Effendy, 2013, Korupsi dan Strategi Nasional-Pencegahan Serta Pem-berantasannya, Referensi (GP Press Group), Jakarta, p. 157-158.

${ }^{30}$ Ade Mahmud, 2020, Pengembalian Aset Tindak Pidana Korupsi Pendekatan Hukum Progresif, First Printing, Sinar Graphic, Jakarta, p. 122.
} 
Faculty of Law, UNISSULA Semarang, p. 844, url : http://jurnal.unissula.ac.id/index.php/RH/article/view/3412/2521.

[2] Hulman Siregar, March 2018, Rumusan Pidana dan Pemidanaan Tindak pidana Korupsi Yang Merugikan Keuangan Negara Serta Permasalaan Dalam Penerapannya, Jurnal Daulat Hukum, Vol. 1. No. 1, Faculty of Law, UNISSULA, Semarang

[3] Luk Har Syan'in, Gunarto, and Widayati, March 2019, Criminal Investigation Polres Kudus Unit Efforts In The Prevention Of The Corruption In Village Funds Management, Jurnal Daulat Hukum, Vol. 2 No. 1, Faculty of Law, UNISSULA Semarang, p. 69, url : unissula.ac.id/index.php/RH/article/view/4208/2914.

[4] Muhamad Riyadi Putra and Gunarto, Analysis Of Handling Practices On Corruption Crime By Police (Case Study In Special Criminal Investigation Police Directorate Of Central Java), Jurnal Daulat Hukum, Vol. 2 No. 2, Faculty of Law, UNISSULA Semarang, June 2019, p. 209, url : http://jurnal.unissula.ac.id/index.php/RH/article/view/5425/3346.

[5] Rakhmat Bowo Suharto and Cipto Dwi Leksana, Maret 2019, Implementation of Cooperation Agreement Between the Ministry of Internal Affairs, Police, Attorney General Office (Ago) in Handling and Crime OfCorruption in Indonesia, Jurnal Daulat Hukum, Vol. 2 No. 1, Faculty of Law, Universitas Islam Sultan Agung, Semarang, p. 123, url : http://jurnal.unissula. ac.id/index.php/RH/article/view/4217/2923.

\section{Book}

[1] Ade Mahmud, 2020, Pengembalian Aset Tindak Pidana Korupsi Pendekatan Hukum Progresif, First Printing, Sinar Graphic, Jakarta

[2] Agustinus Herimulyanto, 2019, Sita Berbasis Nilai Pengembalian Aset Tindak Pidana Korupsi, First Printing, Genta Publishing, Yogyakarta

[3] Bambang Setyo Wahyudi, 2016, Pengembalian Kerugian Negara Melalui Tuntutan Pencucian Uang dan Gugatan Perdata, First Printing, Hanif Library, Surakarta

[4] Chuck Suryosumpeno, 2020, Rezim Pemulihan Aset, Antara Dibenci dan Dibutuhkan, First Printing, REQBook, Jakarta

[5] Febby Mutiara Nelson, 2020, Plea Bargaining \& Deferred Prosecution Agreement Dalam Tindak Pidana Korupsi, First Printing, Sinar Graphic, Jakarta

[6] Imam Anshori Saleh, 2017, Korupsi, Terorisme dan Narkoba, Upaya Melawan Kejahatan Luar Biasa yang Sistematis, First Printing, Setara Press, Malang

[7] Jawade Hafidz Arsyad and Dian Karisma, 2018, Sentralisasi Birokrasi Pengadaan Barang \& Jasa Pemerintah, First Printing, Sinar Graphic, Jakarta.

[8] Jawade Hafidz Arsyad, 2013, Korupsi Dalam Perspektif HAN (Hukum Administrasi Negara, First Printing, Sinar Graphic, Jakarta

[9] Jhonny Ibrahim, 2011, Teori dan Metodologi Penelitian Hukum Normatif, Bayumedia, Malang

[10] Makhrus Ali, 2016, Hukum Pidana Korupsi, UII Press, Yogyakarta

[11] Marwan Effendy, 2013, Korupsi dan Strategi Nasional-Pencegahan Serta Pemberantasannya, Referensi (GP Press Group), Jakarta 
[12] Mukti Fajar ND and Yulianto Achmad, 2010, Dualisme Penelitian Hukum Normatif dan Empiris, Pustaka Pelajar, Yogyakarta

[13] Rodliyah and Salim HS, 2019, Hukum Pidana Khusus, Unsur dan Sanksi Pidananya, First Edition, Second Printing, Rajawali Press, Depok

[14] S.R Sianturi, 2012, Asas-Asas Hukum Pidana Di Indonesia dan Penerapannya, Babinkum TNI, Jakarta

[15] Soeratno and Lincolin Arsyad, 2003, Metodologi Penelitian Untuk Ekonomi Dan Bisnis, UPP AMP YKPN, Yogyakarta

[16] Sri Endah Wahyuningsih, 2013, Prinsip-Prinsip Individualisasi Pidana Dalam Hukum Pidana Islam dan Pembaharuan Hukum Pidana Indonesia, Second Printing, Publishing Agency Diponegoro University, Semarang

[17] Sujono, 2020, Pemulihan Aset Korupsi Melalui Pembayaran Uang Pengganti dan Gugatan Perdata Negara, First Printing, Genta Publishing, Yogyakarta

[18] Wahju Prijo Djatmiko, 2020, Politik Kriminal Pemberantasan Tindak Pidana Korupsi Perspektif Budaya Hukum, Sixth Printing, Thafa Media, Yogyakarta 